\title{
Effectiveness of Counseling on Mother's Ability in Early Detection of Young Baby Hazard Signs
}

\author{
Sri Sukamti ${ }^{1}$, Novita Rina Antarsih ${ }^{2}$ \\ ${ }^{1,2}$ Department of Health Polytechnic of Ministry of Health Jakarta III, Indonesia \\ Email: sukamtisri@yahoo.com
}

\begin{abstract}
Integrated Management of Young Babies (MTBM) is a method for teaching parents how to care for a child at home; Counseling parents to solve feeding problems, and advising parents about when to return to a health facility. There is no evaluation of the effective implementation of counseling on ICMI/MTBS services to the knowledge or ability of mothers to treat and detect early signs of the danger of the baby's. This study aims to determine the effectiveness of counseling in the service of MTBM on the ability of mothers to detect early signs of danger for young infants aged $<2$ months. The research method uses a quasi-experimental design with one group of pre and post-test approaches. Sample of 35 babies taken in the Ciri Mekar District Health Center in Bogor in 2019. There was a significant difference in the average knowledge of mothers about basic care of young infants before and after counseling in the MTBM service $p$-value of 0.001 , and there was a significant difference in the average ability of mothers about the detection of danger signs of young infants before and after counseling in the service of MTBM p-value 0.028. Counseling given to baby mothers less than 2 months in MTBM service is effective to improve mother's knowledge about young baby's basic care and the danger signs detection of the young.
\end{abstract}

Keywords: Counseling, Danger Signs of Young Babies, Knowledge.

\section{A. INTRODUCTION}

According to WHO in 2018, 47\% neonatal mortality rate is the newborn [1, 2]. More than 10 million children die each year in developing countries before they reach their fifth birthday [3]. The main causes of this death are the complications of premature birth, pneumonia, birth asphyxia, congenital anomalies, diarrhea, and malaria. It can be prevented or treated with immunization, adequate nutrition, clean water, food and proper care by a well-trained healthcare provider when needed [4]. The results of the Indonesian Demographic and Health Survey (SDKI) 2017 showed that infant mortality rate is 24 per 1000 live births while the infant mortality rate in Indonesia is still high enough when compared to Southeast Asian countries, i.e. 32 per 1000 of live births [5].

The global burden of disease indicates that these conditions will continue to be major contributors to child deaths in the year 2020. Every day, millions of parents take children with potentially fatal illnesses to first-level health facilities. WHO and UNICEF developed a strategy known as Integrated Management of Childhood Illness (IMCI). This guideline are designed for the management of sick children aged 1 week up to 5 years. They promote evidence-based assessment and management, using a syndromic approach that supports the rational, effective, and affordable use of drugs. They include methods for assessing signs that indicate severe disease; 
assessing a child's nutrition, immunization, and feeding; teaching parents how to care for a child at home; counseling parents to solve feeding problems, and advising parents about when to return to a health facility. Its guidelines also include recommendations for checking the parents' understanding of the advice given and for showing them how to administer the first dose of treatment. The approach in this handbook ensures the thorough assessment of common serious conditions, nutrition, and immunization; promotes rapid and affordable interventions; strengthens the counseling of caretakers and the provision of preventive services; and assists health care providers to support and follow national guidelines. The IMCI process can be used by doctors, nurses, and other health professionals who see sick infants and children aged from 1 week up to five years [3,6]. ICMI in Indonesia is adapted in the Integrated Management Sick Toddler (MTBS), while the Integrated Management of Childhood Illness: management of the sick young infant aged up to 2 months, in the form of Integrated Management of Young Babies (MTBM) [7-9].

The result of the evaluation of MTBS implementation and compliance at Yogyakarta Public Health Center was obtained on average - 60\% compliance for all MTBS services, while for $85 \%$ counseling. The result of the evaluation of MTBS compliance in the West, central and eastern region of Indonesia has been conducted by the Ministry of Health with an overall yield of western and central regional averages of $58.2 \%$ and Eastern regional $50.9 \%$, while the lowest compliance is counseling on the western and central regional $42.7 \%$, Eastern regional $25.8 \%$. Also, health officers who inform when the child should return immediately only $44.6 \%$ provide information [10]. Knowledge of women with the postpartum period about the danger signs of a newborn respondent with a good level of knowledge, which is as many as 14 respondents $(24.1 \%)$, respondents with enough knowledge of 34 respondents $(58.6 \%)$, and most of the knowledge level is less, which is as much as 10 respondents (17.2\%) [11]. Implementation of counseling on ICMI/MTBS services to the knowledge or ability of mothers to treat and detect early signs of the danger of the baby's not yet known for its effectiveness.

\section{B. METHODS}

This research is a quantitative research using a quasi-experiment with the design of one group pre-post-test design. The study provided intervention in the form of counseling in MTBM service, then measured the knowledge of mothers in early detection of the danger of a young baby with less than 2 months before and after counseling and confounding variables are age, education, and occupation. Research conducted in the Public Health Center Ciri Mekar Bogor Regency in July until October 2019. The number of samples from each group was 35 people with purposive sampling techniques and criteria of inclusion of mothers who have babies less than two months and babies visit neonatal healthy or with health problems. The analysis used sufficient analysis is conducted using a Wilcoxon test to compare the mean before with the following counseling. 


\section{RESULT AND DISCUSSION}

The distribution characteristics of respondents at the Ciri Mekar Community Health Center in Bogor Regency in 2019 are as follows:

Table 1 Distribution Characteristic of Respondents in the Public Health Center Ciri Mekar Bogor Regency Year 2019

\begin{tabular}{|c|c|c|c|c|}
\hline Variable & & & $\mathbf{f}$ & $\%$ \\
\hline \multicolumn{5}{|l|}{ Mother occupation } \\
\hline Housewife & & & 30 & 85,7 \\
\hline Employed & & & 5 & 14,3 \\
\hline \multicolumn{5}{|l|}{ Education } \\
\hline SD & & & 3 & 8,6 \\
\hline SMP & & & 9 & 25,7 \\
\hline SMA & & & 18 & 51,4 \\
\hline PT & & & 5 & 14,3 \\
\hline Variable & Mean & Median & SD & Min-Max \\
\hline Age of mothers & 30,6 year & 31 & 6,2 & $18-41$ \\
\hline Infant Age & 19,9 day & 12 day & 16 & $1-58$ \\
\hline Initial upbringing knowledge & 86,4 & 85 & 7,8 & $71-100$ \\
\hline After-care knowledge & 95,6 & 100 & 8,1 & $71-100$ \\
\hline Early Hazard detection knowledge & 82,6 & 78 & 7,4 & $71-100$ \\
\hline Hazard detection Knowledge After & 87,6 & 92 & 11,0 & $57-100$ \\
\hline
\end{tabular}

Based on the results of the study obtained $85.7 \%$ the mother of the infant is housewife, $51.4 \%$ educated SLTA, $14.3 \%$ educated college. Average age-maternal baby 30.6 years, minimum 18 years, and maximum age 41 years, average baby age 19.9 days with a minimum of 1 day and a maximum of 58 days. The baby's mother has initial knowledge of the young baby's upbringing with an average of 86.4 and knowledge after counseling on the care of young babies with an average of 95.6. The mother's early knowledge of the danger detection in the average young baby is 82.6 and the knowledge after counseling on danger detection on average young babies is 87.6.

Table 2 Distribution of Characteristics and Knowledge of Basic Care of Young Babies in the Public Health Center Ciri Mekar Bogor Regency Year 2019

\begin{tabular}{lccc}
\hline \multicolumn{1}{c}{ Variable } & Mean Rank & P Value & n \\
\hline Low education & 15,79 & 0,365 & 12 \\
Higher education & 19,15 & & 23 \\
\hline Healthy reproductive Age & 18,24 & 0,843 & 25 \\
Age at risk & 17,40 & & 10 \\
\hline Housewife & 17,65 & 0,631 & 30 \\
Employed & 20,10 & & 5 \\
\hline
\end{tabular}


Nonparametric analysis results in. There is no difference in the average young baby's knowledge on the level of education ( $p$-value 0.365), Mother's age (p-value 0.843), Mother occupation (P-value 0.631).

Table 3 Distribution of Characteristics and Knowledge of Danger Signs Detection of Young Babies in the Public Health Center Ciri Mekar Bogor Regency Year 2019

\begin{tabular}{lccc}
\hline \multicolumn{1}{c}{ Variable } & Mean Rank & P value & n \\
\hline Low education & 17,38 & 0,797 & 12 \\
Higher education & 18,33 & & 23 \\
\hline Healthy reproductive Age & 16,92 & 0,339 & 25 \\
Age at risk & 20,70 & & 10 \\
\hline Housewife & 18,68 & 0,345 & 30 \\
Employed & 13,90 & & 5 \\
\hline
\end{tabular}

Nonparametric analysis results. There is no difference in the average knowledge of the danger signs of young babies at the level of education ( $p$-value 0.797), Mother's age (p-value 0.339), Mother occupation (P-value 0.345).

Table 4 Basic Knowledge of Young Infants Before and After Counseling on MTBM the Public Health Center Ciri Mekar Bogor Regency Year 2019

\begin{tabular}{lcccc}
\hline \multicolumn{1}{c}{ Variable } & Mean & Mean rank & P Value & n \\
\hline Early knowledge & 86,4 & 11 & 0,0001 & 35 \\
Knowledge after & 95,6 & & & \\
\hline
\end{tabular}

The results of the study obtained early knowledge about the basic care of the young baby 86.4 average, knowledge after the average counseling of 95.6 with mean rank 11, p-value 0.0001, which means statistically significant differences in the average knowledge of mothers about the basic care of young babies before and after counseling on MTBM services.

Table 5 Knowledge Detection of Hazard Signs Before and After Counseling on MTBM services in the Public Health Center Ciri Mekar Bogor Regency Year 2019

\begin{tabular}{lrccc}
\hline Variable & Mean & Mean Rank & P Value & n \\
\hline Early knowledge & 82,6 & 15,6 & 0,028 & \multirow{2}{*}{35} \\
Knowledge after & 87,6 & & \\
\hline
\end{tabular}

The results of the study obtained early knowledge about the detection of the danger signs of average young baby 82.6 and the knowledge after the average counseling -87.6, mean rank $15.6 \mathrm{p}$ value 0.028 means statistically significant difference in the average of maternal knowledge about the detection of the danger of young babies before and after counseling on MTBM services.

The results of this study show that the majority of parents are infants who are not working outside the house in addition to caring for their babies. According to the assumption, researchers do this cause a mother tends to have time to find information on more childcare and more contact with the baby. The majority of mothers are educated high school. According to the researchers it is more likely to 
understand the information and the motivation wants to know better about his knowledge needs that relate to themselves and his family. The average age of mothers is 30.6 years old is a healthy reproductive age and is a middle age who has a healthy reproductive health to have children physically and mentally socially so that the ability to seek knowledge about caring for and nurturing a child is better. The characteristics of this baby mother have a positive value to the level of maternal knowledge about young baby care and early detection of the danger signs of young babies, mother's knowledge of the average young baby's orphanage 86.4 and mother's knowledge of the average young baby's danger detection of 82.6 (table 1).

The characteristics of mothers who include education, employment and the age of mothers statistically have no association with the knowledge of mothers about the care of young babies, this does not mean that the substance characteristics are not meaningful because the education of a person will affect the way of thinking and analysis of information received by someone. One with higher education will better analyze and receive information rationally. The age of healthy reproduction is an excellent age for a pregnant woman, childbirth, and puzzle, in this age physically, mentally, and emotionally a woman is ripe so that it will be easy to face a change in her and the surrounding family. While a working mother will be less time along with her baby and understand the baby's condition well. The home mother will have time to understand her baby's condition and look for information according to her baby's condition from family, friends, or other sources (table 2).

The characteristics of mothers who include education, employment and the age of mothers statistically have no association with the knowledge of mothers about the detection of the danger signs of young babies, this does not mean that the characteristics of the substance are not meaningful because the education of a person will affect the way of thinking and analysis of information received by someone. One with higher education will better analyze and receive information rationally. The age of healthy reproduction is an excellent age for a pregnant woman, childbirth, and puzzle, in this age physically, mentally, and emotionally a woman is ripe so that it will be easy to face a change in her and the surrounding family. While a working mother will be less time along with her baby and understand the baby's condition well. The home mother will have time to understand her baby's condition and look for information according to her baby's condition from family, friends, or other sources (table 3).

It is likely because in conducting counseling using an MTBM guide from $\mathrm{WHO}$ has been adapted into the Indonesian language so that it is easy to understand mother so that there is an increase in the knowledge and ability of mothers in detecting signs of danger in infants. If one gets a lot of information/data then it tends to have higher knowledge. The source of information is official and unofficial documents, primary, literature, electronic, media, and information sources obtained from healthcare personnel [12]. Information obtained from various sources will affect a person's level of knowledge [13]. The study in urban China showed that although over half of the patients with diabetes had received Medical Nutrition 
Therapy/MNT education, over half of the patients still had poor understanding and practices of MNT, and the control rate of blood glucose was still very low. Patients with higher KAP scores were with better control of blood glucose [14]. While the influence of counseling intervention on women's knowledge, the practice and lifestyle of fetal welfare among primigravidae is a statistically significant improvement knowledge, health, and lifestyle practices and satisfaction of women after application counseling interventions compared to before counseling interventions [15]. Another study report that counseling with a skills training approach (STA) resulted in improved maternal functioning in all domains [16]. Moreover, prenatal counseling can be increasing the level of knowledge and improving the practice of postpartum care in primigravida women [17].

ICMII guidelines include treatment in the clinic also involves counseling the mother or caretaker about counseling differs between sick young infants and sick children, counseling about HIV infection, having possible serious bacterial infection or very severe disease for referral, feeding, fluids, breastfeeding and possible relaxation, immunization, and feeding; teaching parents how to care for a child at home; counseling parents to solve feeding problems, and advising parents about when to return to a health facility/schedule follow up visits for that time. $[3,6,7]$ Counseling from care providers with mothers, including ASK AND LISTEN, PRAISE, ADVISE, AND CHECK UNDERSTANDING. it is important to have good communication with the mother from the beginning of the visit. Using good communication helps to reassure the mother that her child will receive good care. [3,9] Strategies increased counseling are relatively simple steps that have shown promise in increasing community to facility referral and compliance with referral [18].

\section{CONCLUSION}

The maternal characteristics that include education, employment, and the age of mothers statistically have no association with the knowledge of mothers about the care of young babies. While counseling given to baby mothers less than 2 months in MTBM Service is effective to improve mother's knowledge about young baby's basic care and the danger signs detection of the young baby so that it can prevent morbidity and mortality of infants aged less 2 months.

\section{REFERENCES}

1. WHO. (2019). Infant mortality [Internet]. Retrieved from: http://www.who.int/gho/child_health/mortality/neonatal_infant/en/

2. WHO. (2019). Neonatal mortality [Internet]. Retrieved from: http://www.who.int/gho/child_health/mortality/neonatal/en/

3. WHO. (2005). Handbook: IMCI integrated management of childhood illness.

4. WHO. (2019). Children: reducing mortality [Internet]. Retrieved from: https://www.who.int/news-room/fact-sheets/detail/children-reducing-mortality 
5. BKKBN, BPS, Kemenkes RI, USAID. (2018). Survei Demografi dan Kesehatan Indonesia (SDKI) 2017. Indonesia: BKKBN, BPS, Kemenkes RI, USAID.

6. WHO. (2019). Integrated Management of Childhood Illness: management of the sick young infant aged up to 2 months. IMCI chart booklet. Geneva: UNICEF-WHO.

7. Kemenkes RI. (2019). Buku Bagan: Manajemen Terpadu Balita Sakit (MTBS). Jakarta: kemenkes RI.

8. Depkes RI, USAID, WHO. (2008). Manajemen Terpadu Balita Sakit: Modul 5: Manajemen Terpadu Bayi Muda Umur Kurang Dari 2 Bulan. Jakarta: Depkes RI.

9. Depkes RI, USAID, WHO. (2008). Manajemen Terpadu Balita Sakit: Modul 4: Konseling pada Ibu. Jakarta: Depkes RI.

10. Suparmi, S., Maisya, I. B., Rizkianti, A., Sari, K., Rosha, B. C., Amaliah, N., ... \& Daisy, L. (2018). Pelayanan Manajemen Terpadu Balita Sakit (MTBS) pada Puskesmas di Regional Timur Indonesia. Media Penelitian dan Pengembangan Kesehatan, 28(4), 271-278.

11. Hidayah, N., \& Wulandari, F. (2016). Analisa Pengetahuan Ibu Nifas Terhadap Tanda Bahaya Bayi Baru Lahir. Profesi (Profesional Islam): Media Publikasi Penelitian, 14(1), 62-66.

12. Notoatmojo, S. (2010). Promosi Kesehatan dan Ilmu perilaku. Jakarta: Rineka Cipta.

13. Wawan, A., \& Dewi, M. (2010). Teori dan Pengukuran Pengetahuan, Sikap dan Perilaku Manusia. Yogyakarta: Nuha Medika.

14. Li, Z., Jin, H., Chen, W., Sun, Z., Jing, L., Zhao, X., ... \& Guo, X. (2017). Influencing Factors of Knowledge, Attitude, and Practice Regarding Medical Nutrition Therapy in Patients with Diabetes: A National Cross-Sectional Study in Urban China. Journal of diabetes research, 1-7.

15. Ahmed, A. (2016). Effect of Counseling Intervention on Women's Knowledge, Practices and Lifestyle of Fetal Well-being among Primigravidae. International Journal of Nursing Science, 6(4), 87-93.

16. Chamgurdani, F. K., Barkin, J. L., Esmaeilpour, K., Malakouti, J., Buoli, M., \& Mirghafourvand, M. (2020). The effect of counseling with a skills training approach on maternal functioning: a randomized controlled clinical trial. BMC Women's Health, 20(1), 1-10.

17. Soltanni, F., Esmaeili, M., Mohammadi, Y., \& Aghababaei, S. (2019). The Effect of Prenatal Counseling on the Knowledge and Performance about Postpartum Care in Primigravida Women. Avicenna Journal of Nursing and Midwifery Care, 27(5), 344-351.

18. WHO. (2006). Management of Sick Children by Community Health Workers: Intervention Models and Programme Examples. UNICEF-WHO. 